\title{
Geodynamic and geophysical consequences of stealth(y) mantle metasomatism: craton evolution and metallogeny
}

\author{
Suzanne Y. O'Reilly ${ }^{1}$, William L. Griffin ${ }^{1}$ and Norman J. Pearson ${ }^{1}$ \\ ${ }^{I}$ ARC Centre of Excellence for Core to Crust Fluid Systems (CCFS) and GEMOC, Earth and Planetary \\ Sciences, Macquarie University, NSW 2109,Australia; sue.oreilly@mq.edu.au; bill.griffin@mq.edu.au. \\ norman.pearson@mq.edu.au
}

\section{Introduction}

The metasomatised lithospheric mantle is a palimpsest, recording the multiple events that have affected that domain since it formed. Interpreting this complex record and tracking specific episodes and processes is a key to reconstructing lithosphere evolution through time, and the nature of volatile fluxes from the deep Earth. Convergence between datasets of Hf isostopic model ages for zircons (e.g., Belousova et al., 2010) and Re-Os model ages for mantle sulfides (Griffin et al., 2014), reinforced by other geochemical and tectonic criteria, indicate that over $75 \%$ of the subcontinental lithospheric mantle (SCLM) and its overlying crust (now mostly lower crust) formed at 3.0-3.5 Ga, probably in global overturn events that marked a change in Earth's fundamental geodynamic behaviour (Griffin et al, 2014).

Pristine Archean lithospheric mantle, the roots of the Archean cratons up to $>300 \mathrm{~km}$ deep, is not only more depleted (low in basaltic melt components) than younger lithospheric mantle, it is differently depleted. Proterozoic and Phanerozoic lithospheric mantle (xenoliths and orogenic massifs), as well as abyssal peridotites, ophiolitic peridotites, all have one important feature in common: as Al decreases, $\mathrm{Fe}$ (and $\mathrm{Cr}$ ) contents show only a very narrow range $(8 \pm 1 \mathrm{wt} \% \mathrm{FeO})$. In contrast, Archon peridotites have lower $\mathrm{Fe}$ at low $\mathrm{Al}$ contents, and may show a weak positive correlation between $\mathrm{Fe}$ (and $\mathrm{Cr}$ ) and $\mathrm{Al}$, suggesting that no $\mathrm{Cr}-\mathrm{Al}$ phase (i.e. spinel or garnet) was present on the liquidus during the melting that produced Archean lithosphere. Garnet-peridotite suite rocks in cratonic mantle are thus now interpreted as products of the metasomatic introduction of garnet and clinopyroxene into original depleted harzburgite, thus "refertilising" the depleted residue. Therefore, the "oceanic melting trend" of Boyd (1989) is now intepreted as a refertilisation trend, with the compositional trend arrow reversed (Griffin et al., 2009). The cratonic roots in contact with the asthenosphere, and their vertical margins in contact with repeated fluid and melt fluxes, are the most strongly modified domains through time, so cratonic root compositions show a general increase in fertility with increasing depth.

Integration of geochemical and geophysical datasets, groundtruthed with petrophysical measurements and modelling for different mineral compositions and modes, has enabled geologically realistic interpretations of global (and regional) tomographic results, identifying the vertical and horizontal extent of original Archean cratonic mantle and their refertilised domains (Figure 1).

\section{Stealth Metasomatism and its Geophysical Significance}

Metasomatism (and associated refertilisation) affects not only the geochemical characteristics of the lithospheric mantle, but also its physical parameters (and hence geophysical signatures) including density, seismic response and thermal and electrical characteristics. The concept of "stealth" metasomatism has been introduced to highlight the "deceptive" addition to lithospheric mantle rocktypes of new phases (e.g. garnet and/or clinopyroxene) indistinguishable mineralogically from common mantle-peridotite phase assemblages.

Recognition of stealth metasomatism reflects the increasing awareness of the importance of refertilisation of ancient refractory mantle regions by metasomatic fluid fronts in modifying mantle domains. Understanding the timing and nature of stealth metasomatism is critical to understanding the geochemical and geodynamic evolution of the lithospheric mantle domains and assessing their metallogenic fertility. 
Primitive Archean lithospheric mantle is highly magnesian ( 49\% MgO) with lower density ( 3.31 $\left.\mathrm{g} / \mathrm{cm}^{3}\right)$ than fertile mantle $\left(\sim 3.37 \mathrm{~g} / \mathrm{cm}^{3}\right)$. The resulting contrasts in seismic response become measurable if metasomatised regions are on the scale of tens to hundreds of $\mathrm{km}$. Metasomatic refertilisation of the cratonic lithospheric mantle not only increases its density, but also strongly affects its rheology. The recognition that the cratonic lithospheric mantle may in general consist of a very depleted upper layer, becoming more metasomatised (evidenced by garnet peridotites) at depth, provides a solution to some important discrepancies between geophysical data and numerical models. A deep cratonic root made up mainly of garnet peridotites would imply a lower geoid and a much greater elevation than is observed for the Kaapvaal craton, and a mismatch in $\mathrm{Vp} / \mathrm{Vs}$ ratios (Afonso et al., 2010), but a layered model in with refertilization increasing with depth, yields numerical models that fit the geophysical data.
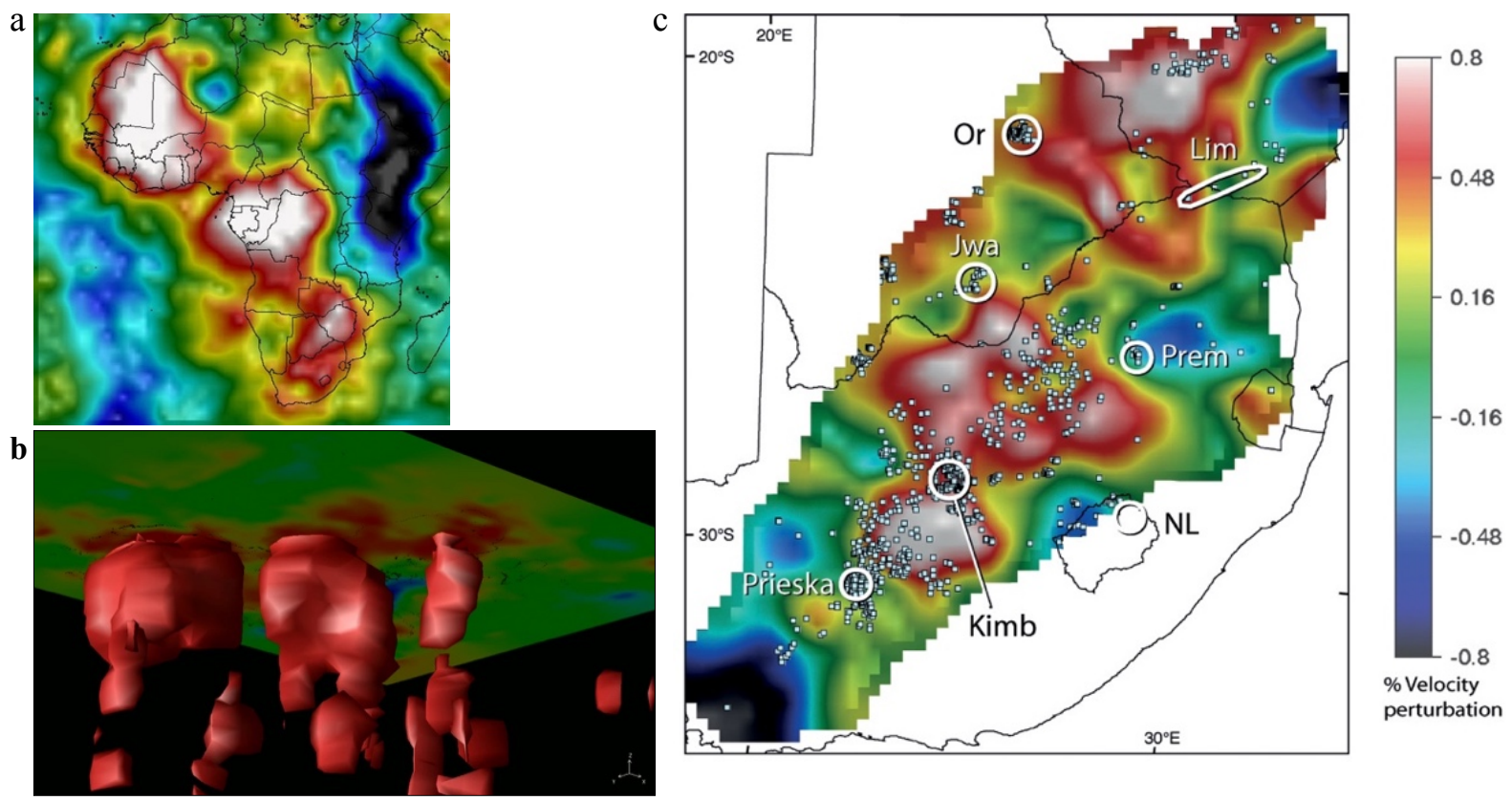

Figure 1: Vs tomography $(100-150 \mathrm{~km})$ of the lithospheric mantle . Red to white colours indicate high Vs; blue colours low Vs (modified from Griffin et al., 2013 and Begg et al., 2009). (a) Africa, showing distribution of the boundaries of high-velocity cratonic blocks with metasomatised (red) margins. (b) modelled high-Vs irregular volume of cratonic roots to $\sim 350 \mathrm{~km}$ beneath each craton. (c). Detailed seismic tomography for Kaapvaal craton with kimberlites clustered at margins of high-velocity volumes. White circles show major kimberlite provinces.

Thermal changes are caused by advective transfer of heat by relatively hot metasomatising fluids and by the influx of heat-producing elements $(\mathrm{K}, \mathrm{U}, \mathrm{Th})$ that accompanies some types of metasomatism. Radioactive decay of these elements can raise the local heat flow by $50-70 \%$ over normal reduced mantle heat flow. The origins of significantly contrasting electromagnetic (MT) responses in the lithospheric mantle have not yet been satisfactorily identified. Fluid-related recrystallisation demonstrated in microstructural studies may result in significant $\mathrm{H}$ contents in mantle minerals and may affect electrical conductivity. The key to understanding the electromagnetic signals from the mantle lies in identifying the nature of fluids and their distribution and thus is closely connected with a full understanding of metasomatic processes, grain sizes and fabrics, and fluid compositions and movement mechanisms in the mantle. Comparisons of high-resolution MT traverses with geochemical mapping traverses show a correlation of higher conductivity with more strongly metasomatised domains.

\section{Implications for metallogeny}

Magma-related ore systems form economic deposits that underpin our human civilisation. The magmas related to metallic element redistribution derive from the asthenosphere, then traverse and interact to 
varying degrees with the subcontinental lithospheric mantle. The evolution of the original Archean lithospheric mantle has been the single largest influence on the formation of most of Earth's ore deposits (Griffin et al., 2013):

- the high degree of buoyancy of this ancient SCLM relative to the asthenosphere, results in the persistence today of low-density, rheologically coherent Archean domains and commonly, the preservation of old crustal (or at least lower-crustal) domains;

- the enduring (and volumetrically dominating) Archean lithospheric mantle domains are a reservoir for metasomatic enrichment over their long history, creating a potentially metallogenically-fertile mantle impregnated with critical elements (e.g., $\mathrm{Au}, \mathrm{Cu}$, Ni and PGEs (Zhang et al., 2008);

- the formation of Archean cratons provided an architectural mantle-scape of regions with contrasting rheology, composition and thickness. These cohesive Archean domains direct magma and fluid pathways around their margins and along old sutures between blocks, and may act as both sinks and sources for ore-forming elements depending on the geodynamic evolutionary stage;

- if the first stabilisation of lithospheric mantle at 3.0-3.5 Ga signalled the end of a mantle overturn regime (either uniquely, or intermittently with subduction), then this is when long-lived tectonic regimes conducive to mineralising systems (e.g. back-arc basins, passive margins, cratonic boundaries) became available Begg et al., (2010).

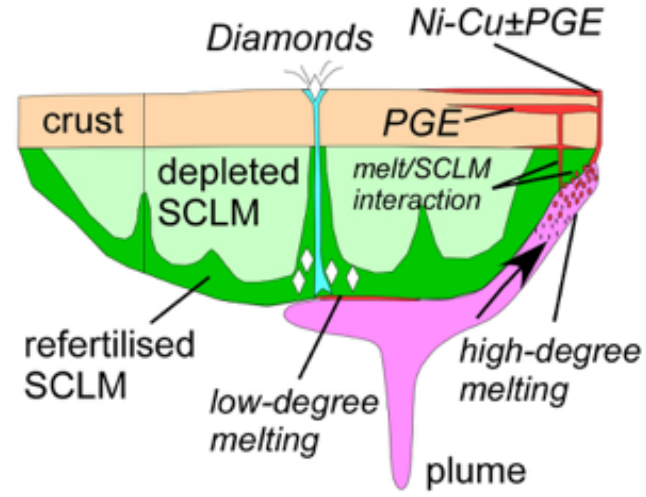

Figure 2: Interactions between magmas and the base and edges of cratonic roots. Plume magmatism triggers kimberlite formation and flows to areas of thinner SCLM where melting is focused. Variable interaction of melts with crust and SCLM influences $\mathrm{Ni}-\mathrm{Cu}$ and PGE deposit genesis. Lithosphere-scale discontinuities and zones of weakness can focus the locus of kimberlite eruption.

\section{References}

Afonso JC, Ranalli G, Fernandez M, et al. (2010) On the Vp/Vs-Mg\# correlation in mantle peridotites: Implications for identification of thermal and compositional anomalies in the upper mantle. Earth Planet Sci Lett 289: 606-618

Begg GC, Griffin WL, Natapov LM, et al. (2009) The lithospheric architecture of Africa: Seismic tomography, mantle petrology and tectonic evolution. Geosphere 5: 23-50

Begg GC, Hronsky JAM, Arndt NT, et al. (2010) Lithospheric, cratonic, and geodynamic setting of NiCu-PGE sulfide deposits. Econ. Geology 105: 1057-1070

Belousova EA, Kostitsyn YA, Griffin WL, et al. (2010) The growth of the continental crust: Constraints from zircon Hf-isotope data. Lithos 119: 457-466

Boyd FR (1989) Composition and distinction between oceanic and cratonic lithosphere. Earth Planet. Sci. Lett., 96: 15-26

Griffin, W.., O'Reilly, S.Y., Afonso, J.C., Begg, G.C., 2009. The composition and evolution of lithospheric mantle: A re-evaluation and its tectonic implications. J. Petrology 50(9): 1185-1204

Griffin WL, Begg GK, O'Reilly SY (2013) Continental-root control on the genesis of magmatic ore deposits. Nature Geoscience 6: 905-910

Griffin WL, Belousova EA, O'Neill C, et al. (2014) The world turns over: Hadean-Archean crustmantle evolution. Lithos 189: 2-15

O’Reilly SY, Zhang M, Griffin WL, Begg G, Hronsky J, 2009. Ultradeep continental roots and oceanic remnants: a solution to the geochemical "mantle reservoir" problem? Lithos 112(2): 1043-1054

Zhang M, Wang K-L, O'Reilly SY, Hronsky J, Griffin WL (2008) Flood basalts and metallogeny: The lithospheric mantle connection. Earth Science Reviews 86: 145-174 